Teresa Korbutowicz

Uniwersytet Wrocławski

Instytut Nauk Ekonomicznych

teresa.korbutowicz@uwr.edu.pl

\title{
Żywność funkcjonalna w Unii Europejskiej - pojęcie, wymagania i rozwój rynku
}

Artykuł nadesłany: 30 maja 2017 r.; artykuł zaakceptowany: 15 grudnia 2017 r.

JEL Classification: I19, L66

Keywords: functional foods, nutrition claims, health claims

\begin{abstract}
Functional foods in the European Union - the concept, requirements and development of markets

The interest of consumers in maintaining good health and the development of technology increase the importance of functional foods in the food markets. The functional foods themselves have a beneficial effect on health over nutritional value. It is not explicitly defined for the variety of food products included in this category.

Undoubtedly the so-called health trend in societies afflicted with civilization diseases (e.g. obesity, diabetes, cardiovascular disease, cancer) has changed the consumer's attitude towards food. The knowledge about the relationship between quality of food consumption and quality of life, especially a state of health of people was increased. The answer to these trends is the growing number of functional foods that are provided by entrepreneurs. There is also a growing consumption of such food in the world and European countries.
\end{abstract}

\section{Wstęp}

Rozwój technologii przyczynił się do pojawienia się na rynkach światowych produktów żywnościowych określanych mianem żywności funkcjonalnej czy bioaktywnej. Produkcja i spożycie takich produktów rośnie głównie w Azji, USA i Europie. Żywność bioaktywna wyróżnia się tym, że wpływa na zdrowie człowieka, a przez to ogranicza i zapobiega występowaniu chorób cywilizacyjnych. 
Celem artykułu jest określenie charakteru żywności funkcjonalnej, jej klasyfikacji oraz wymogów, jakie musi spełnić, a także wskazanie, jakie są tendencje na rynku takich produktów. Rozwój rynku żywności funkcjonalnej zależy od postępu badań nad produktami spożywczymi i ich składnikami, zmian nawyków żywieniowych konsumentów i zapewnienia bezpieczeństwa żywności. Utrzymujący się trend prozdrowotny sprzyja wzrostowi produkcji i wartości tego rynku.

\section{Teoretyczny aspekt badań}

Badania nad żywnością funkcjonalną dotyczą samego pojęcia, jego zakresu i rodzajów żywności (Doyton, Labrecque 2005; Roberfroid 2002; Malla et al. 2013), a także wpływu na zdrowie konsumentów (Grajeta 2004; Holm 2000; Functional Foods 2010). Programy naukowe, w tym te realizowane w UE, służą temu celowi oraz dostarczają podstaw do określenia warunków oświadczeń zdrowotnych, które zmierzają do zapewnienia bezpieczeństwa konsumenta (Pravst 2012; Ashwell 2001). Zdefiniowanie tego terminu ma znaczenie $\mathrm{z}$ uwagi na ustalenie wartości i wielkości obrotu żywnością, rozwoju rynku produktów funkcjonalnych i występujących na nim tendencji, zachowań konsumenta (Vicentini, Liberadore, Mastrocola 2016; IRC Scientific and Technical Reports 2008).

\section{Metodologia badań}

Podstawową metodą badawczą jest analiza warunków prawnych w UE, odnoszących się do dopuszczenia żywności do obrotu (oświadczenia żywieniowe i zdrowotne), raportów Europejskiego Urzędu ds. Bezpieczeństwa Żywności oraz raportów o stanie rynku żywności funkcjonalnej. W badaniach wykorzystano tradycyjne studia literaturowe oraz dane statystyczne Euromonitora.

\section{Pojęcie żywności funkcjonalnej}

Termin „żywność funkcjonalna” obejmuje zarówno ogólnie dostępne produkty spożywcze, jak i żywność wzbogaconą, zmodyfikowaną lub ulepszoną, a także suplementy dietetyczne, z których każdy ma właściwości poprawiające zdrowie psychiczne i fizyczne oraz zmniejszające ryzyko występowania chorób. Z uwagi na dużą różnorodność produktów zaliczanych do żywności funkcjonalnej niezależnie od siebie używane są liczne definicje i określenia tego pojęcia, takie jak FOSHU ${ }^{1}$, nutraceutyki, żywność o działaniu bioleczniczym, żywność farmaceutyczna czy terapeutyczna (Doyton, Labrecque 2005, s. 4). Żywność tego typu charakteryzuje się tym, że w procesie produkcji wprowadza się do niej składnik aktywny biologicznie, naturalnie występujący w mniejszym stężeniu, lub taki, który normalnie

${ }^{1}$ FOSHU, czyli Foods for Specified Health Use, to angielska nazwa nadana japońskiej żywności funkcjonalnej. 
nie jest zawarty w danym produkcie spożywczym; w grę wchodzi też usuwanie z żywności składników zdrowotnie niepożądanych. Tak udoskonalona żywność ma przynieść ściśle określone korzyści, dlatego często nazywana jest żywnością projektowaną do określonych potrzeb organizmu (Saluk-Juszczak et al. 2010, s. 528).

FOSHU, czyli żywność o określonym przeznaczeniu zdrowotnym, zgodnie z przyjętą w japońskim prawie definicją, to produkty żywnościowe, po spożyciu których oczekuje się poprawy stanu zdrowia. Produkty te są opatrzone etykietami, na których deklaruje się, że osoba spożywająca je w celu poprawy stanu zdrowotnego może spodziewać się korzystnego rezultatu. FOSHU jest obok żywności zawierającej funkcjonalne składniki odżywcze jednym z rodzajów żywności ze specjalnymi żywieniowymi deklaracjami (Grajeta 2004, s. 504). Ten rodzaj żywności wymaga jednak oficjalnego zatwierdzenia.

Drugi rodzaj żywności - Food with Nutritient Function Claims ${ }^{2}$ - to produkty posiadające w swoim składzie witaminy i substancje mineralne. Żywność ta musi spełniać określone prawem normy, aby być dowolnie przetwarzana i rozprowadzana bez potrzeby rejestracji.

W Stanach Zjednoczonych została wyodrębniona i określona grupa produktów żywnościowych nazwana żywnością o działaniu bioleczniczym. Wymaga się, aby ta grupa produktów była stosowana pod kontrolą lekarską w pewnych rodzajach schorzeń, miała należycie określoną charakterystykę żywieniową, została poddana ocenie klinicznej oraz była oparta na udokumentowanych badaniach naukowych. Żywność taka nie znajduje się w normalnej dystrybucji. Agencja ds. Żywności i Leków termin ,żywność funkcjonalna” odnosi do żywności i jej komponentów, które dostarczają korzyści zdrowotnych, poza podstawowym działaniem odżywczym. W USA w przeciwieństwie do Japonii nie istnieją odrębne przepisy prawne dotyczące takiej żywności (Kubiński 2010, s. 934).

W Unii Europejskiej w 1999 roku została przyjęta robocza definicja żywności funkcjonalnej, zaproponowana w dokumencie końcowym programu pod nazwą Nauka o Żywności Funkcjonalnej w Europie (FUFOSE - Functional Food Science in Europe). Program jest finansowany przez Komisję Europejską i ma rozwijać współpracę między różnymi ośrodkami naukowymi i przemysłem spożywczym krajów członkowskich UE. Żywności funkcjonalna została w dokumencie określona jako żywność, która wywiera korzystny wpływ na jedną lub więcej funkcji organizmu ponad efekt odżywczy. Wpływ ten polega na poprawie stanu zdrowia, samopoczucia i/lub na zmniejszeniu ryzyka zachorowania. Taka żywność musi przypominać postacią żywność konwencjonalną. Nie są to tabletki ani kapsułki, ani żadna forma suplementów diety. Żywność funkcjonalna jest przeznaczona do ogólnego spożycia jako uzupełnienie codziennej diety. Wyma-

${ }^{2}$ Food with Nutritient Function Claims (FNFC) to żywność zawierająca funkcjonalne składniki odżywcze; należy do grupy FHC — Food with Health Claims. 
gane jest jednak udowodnienie korzystnego wpływu żywności funkcjonalnej na organizm człowieka (Functional Foods 2010, s. 7; Asp 2002, s. 133).

Prozdrowotne działanie takiej żywności powinno być udokumentowane badaniami klinicznymi, w których uczestniczą ludzie, którym do diety włączono badany artykuł spożywczy. Wymaga się, aby badania zostały prowadzone przez niezależne ośrodki naukowe, obejmowały dużą grupę osób i trwały wystarczająco długo, aby zapewnić obiektywne i stabilne wyniki. Tylko naukowe potwierdzenie właściwości prozdrowotnych pozwala uznać dany produkt za żywność funkcjonalną. Działanie prozdrowotne takiej żywności polega na obniżeniu poziomu cholesterolu, przywracaniu prawidłowego funkcjonowania układu pokarmowego, zwalczaniu stanów zapalnych, zapobieganiu rozwojowi miażdżycy czy wzmacnianiu układu odpornościowego (Grajeta 2004, s. 505; Functional Food 2010, s. 9). Żywność funkcjonalna oddziałuje zatem psychologicznie i fizjologicznie na organizm człowieka, a także wykazuje działanie profilaktyczne.

Zgodnie z Europejskim Konsensusem Naukowej Koncepcji Żywności Funkcjonalnej przypisywane są jej następujące właściwości:

— jest żywnością konwencjonalną — należą do niej produkty spożywcze przeznaczone do codziennego stosowania, jest częścią normalnej diety;

— zawiera naturalne składniki i zwiększone stężenie składnika aktywnego, który nie jest zawarty w danym środku spożywczym lub występuje w nim w nieznacznej ilości, lub został zmodyfikowany;

— działanie na stan zdrowotny organizmu ponad efekt żywieniowy musi być naukowo udowodnione - taki efekt osiągany jest w odniesieniu do wszystkich członków społeczeństwa lub do poszczególnych grup określonych według wieku, układu genetycznego/budowy;

- ma mieć oświadczenie żywieniowe i zdrowotne oparte na badaniach naukowych (Kubiński 2010, s. 933; Ashwell 2001, s. 861; Roberfroid 2002, s. 134).

W materiałach projektu FUFOSE zwrócono uwagę, że rozwój żywności funkcjonalnej wynika z dostrzeżenia zależności pomiędzy dietą, specyficznymi składnikami żywności a zdrowiem. Odżywianie zostało uznane za podstawę zachowania zdrowia i dobrego samopoczucia, a trudności, jakie mają konsumenci w doborze optymalnej diety, sprzyjają rozwijaniu badań, technologii, produkcji i dystrybucji żywności funkcjonalnej. Zainteresowanie taką żywnością oraz zdrowym trybem życia zwiększyło się w krajach europejskich i innych rozwiniętych krajach z uwagi na konsekwencje małej aktywności fizycznej i spożywania nazbyt wysokoenergetycznego pożywienia. Zwiększa to możliwość zachorowań na choroby układu krążenia, cukrzycę, nadciśnienie, co z kolei zwiększa koszty opieki zdrowotnej i obniża jakość życia (Functional Foods 2010, s. 8). Dodatkową okolicznością przemawiającą za używaniem żywności funkcjonalnej jest przedłużenie życia i pojawienie się różnego rodzaju problemów mentalnych, takich jak depresja, trudności z koncentracją i utrata pamięci. 
Kolejne określenie to nutraceutyki ${ }^{3}$, które używane jest w odniesieniu do grupy żywności funkcjonalnej, dla której udokumentowano korzyści medyczne i/lub zdrowotne, w tym zapobieganie chorobom i ich leczenie. Termin ten został wprowadzony w 1989 roku w USA i pod wpływem prowadzonych badań naukowych ulegał ewolucji. Współcześnie nutraceutyki nie są już uznawane za leki. Tworzą je składniki izolowane z żywności, suplementy diety, a także produkty ziołowe, które stosuje się pojedynczo lub łącząc z sobą w celu wykorzystania ich synergicznego działania.

Do nutraceutyków zalicza się substancje biologicznie czynne o udowodnionym działaniu prozdrowotnym, które poprzez swoją aktywność biologiczną oddziałują korzystnie na organizm, zapobiegając rozwojowi niektórych procesów chorobowych. Bioaktywne składniki pożywienia, które wykazują działanie wzmacniające, osłabiające lub modyfikujące funkcje organizmu to na przykład błonnik pokarmowy, oligosacharydy, bakterie kwasu mlekowego, wielonienasycone kwasy tłuszczowe, białka, substancje antyoksydacyjne, lecytyna, flawonoidy, roślinne sterole, stanole (Saluk-Juszczak et al. 2010, s. 529).

W odniesieniu do żywności funkcjonalnej stosowany jest też termin ,żywność projektowana do określonych potrzeb organizmu"; może ona występować w postaci tradycyjnej lub modyfikowanej technologicznie. Żywność w postaci tradycyjnej jest produkowana przeważnie metodami konwencjonalnymi, ale surowce do jej wytwarzania pochodzą ze specjalnych hodowli i upraw, prowadzonych w ściśle określonych warunkach, lub są otrzymywane w wyniku selekcji odmian albo modyfikacji biotechnologicznych, w tym genetycznych. Żywność funkcjonalną modyfikowaną technologicznie otrzymuje się natomiast przez:

- wzbogacanie w poszczególne substancje bioaktywne lub ich kompozycje,

— odpowiednie komponowanie poszczególnych składników recepturowych,

— obniżenie lub stosowanie zamienników składników niepożądanych, na przykład soli, tłuszczu, cholesterolu,

— zwiększenie dostępności i przyswajalności składników odżywczych przez wprowadzenie substancji o działaniu synergicznym lub eliminację substancji antyodżywczych (Grajeta 2004, s. 504).

Z pojęciem żywności funkcjonalnej łączony jest termin ,żywność wzbogacona". Pojęcia te nie są tożsame, chociaż w części się pokrywają (Włodarek 2006, s. 23). Żywność wzbogacona według definicji przyjętej przez WHO w 1994 roku oznacza dodawanie jednego lub więcej składników odżywczych do żywności (witamin, składników mineralnych) niezależnie od tego, czy występują one w żywności naturalnie, czy też nie. Takie wzbogacanie ma zapobiegać niedoborom jednego lub więcej składników występujących w całych populacjach lub ich grupach albo

${ }^{3}$ Nazwa wywodzi się z połączenia dwóch angielskich słów, tj. nutrition — 'żywienie’ i pharmaceutical — 'farmaceutyki'. 
skorygować te niedobory. Taka żywność pozwala uzupełnić brakujące składniki odżywcze do zalecanego poziomu spożycia.

Żywność funkcjonalna może być żywnością wzbogaconą i żywnością niewzbogaconą (Szymecka-Wesołowska 2013). Przykładem może być żywność, w której jeden lub kilka składników zostały zmienione lub wzbogacone w celu poprawy ich właściwości zdrowotnych, na przykład jogurt z dodatkiem probiotyków lub prebiotyków, margaryna z dodatkiem fitosteroli, oleje roślinne z dodatkową witaminą E. Wzbogaconą żywnością funkcjonalną nie są natomiast produkty, z których został usunięty lub zredukowany jeden ze składników, czyli obniżony został poziom zawartości tłuszczy czy cukru.

\section{Podział żywności funkcjonalnej}

W literaturze wyróżnia się wiele rodzajów żywności funkcjonalnej w zależności od przyjętego kryterium podziału. Znaczna ich liczba, z uwagi na wielokierunkowe działanie, może być zaliczona do kilku grup tej żywności jednocześnie. Najczęściej dokonywany jest podział żywności funkcjonalnej ze względu na jej przeznaczenie w celu zaspokojenia określonych potrzeb organizmu (lub potrzeb żywieniowych) oraz ze względu na skład. W ostatnim wypadku wyróżnia się żywność funkcjonalną wzbogaconą (na przykład witaminą A, E, C), niskoenergetyczną (truskawki, maliny, jabłka, porzeczki), wysokobłonnikową (suche ziarna zbóż, otręby), probiotyczną, energetyzującą, niskosodową i niskocholesterolową (jajka o obniżonej zawartości cholesterolu). Z uwagi na przeznaczenie żywność funkcjonalną dzieli się na żywność zmniejszającą ryzyko rozwoju chorób krążenia, zmniejszającą ryzyko rozwoju chorób nowotworowych, zmniejszającą ryzyko rozwoju osteoporozy, dla osób obciążonych stresem, dla osób w podeszłym wieku, dietetyczną dla osób z zaburzeniami metabolizmu i trawienia, dla sportowców, dla kobiet w ciąży i karmiących, dla niemowląt, dla młodzieży w fazie intensywnego wzrostu, wpływającą na nastrój i wydolność psychofizyczną oraz hamującą procesy starzenia (Functional Foods 2010, s. 9; Saluk-Juszczak et al. 2010, s. 531).

Odmiennym kryterium podziału żywności funkcjonalnej jest zakres wiedzy o efektach zdrowotnych tej żywności. Zgodnie z tym kryterium wyróżnia się żywność o wysokim stanie wiedzy o efektach zdrowotnych i żywieniowych, $\mathrm{w}$ tym produkty posiadające $\mathrm{w}$ swoim składzie zamienniki sacharozy, produkty wzbogacane bakteriami fermentacji mlekowej i produkty z zamiennikami tłuszczy w składzie. Drugim rodzajem jest żywność o małym stanie wiedzy na temat efektów żywieniowych i zdrowotnych. Należą do niej produkty naturalne zawierające lub wzbogacane biologicznie aktywnymi składnikami roślinnymi lub organizmami posiadającymi te substancje dzięki modyfikacjom genetycznym (Kudełka 2011, s. 292). 
Żywność funkcjonalna jest także klasyfikowana według jej pochodzenia lub sposobu modyfikacji na:

- naturalne produkty, zawierające składniki pozytywnie wpływające na zdrowie, na przykład błonnik pokarmowy z tradycyjnych ziaren zbóż, który zmniejsza ryzyko chorób sercowo-naczyniowych;

— produkty wzbogacone w składniki przeciwdziałające chorobom i mające pozytywny wpływ na zdrowie, na przykład wapń zawarty w jogurtach probiotycznych, chleb z kwasami omega-3;

— żywność, z której usunięto nieodżywcze substancje, na przykład związki toksyczne lub alergeny;

— naturalne składniki żywnościowe, poprawiające zdrowie przez zwiększenie specyficznych związków w pokarmach dla zwierząt, na przykład jajka lub mięso z wysoką zawartością kwasów tłuszczowych omega-3;

— żywność o właściwościach poprawiających zdrowie, wytwarzana przez modyfikację genetyczną, na przykład jagody bogate w przeciwutleniacze (Holm 2000, s. 5).

Rozwój nauki o żywności funkcjonalnej pozwala na wykorzystywanie coraz większej liczby produktów i zapewnia ich coraz skuteczniejsze działanie. Szczególne znaczenie przypisywane jest probiotykom zawierającym specjalne żywe bakterie (na przykład Lactobacillus acidophilus) korzystnie wpływające na zdrowie konsumentów. Szczepy bakterii spożyte we właściwej ilości zachowują i wzmacniają prawidłową florę bakteryjną, zmniejszają stężenie cholesterolu we krwi i zarazem ryzyko rozwoju miażdżycy (Grajeta 2004, s. 506; Saluk-Juszczak et al. 2010, s. 534-535). Tradycyjnie wytwarzane fermentowane produkty mleczne zaliczane są do tej kategorii żywności. Mogą one zawierać jeden ze szczepów bakterii, który dla poprawy walorów smakowych uzupełniany jest szczepami probiotycznymi (Kunachowicz, Kłys 2002, s. 36).

Produkty spożywcze, w tym artykuły mleczarskie, mogą zawierać składniki prebiotyczne, które oprócz wartości odżywczych wywierają korzystny wpływ na zdrowie człowieka poprzez stymulowanie zarówno rozwoju rodzimej mikroflory bakteryjnej, jak i tej dodanej do żywności. Prebiotyki to nietrawione składniki pożywienia, pobudzające wzrost i/lub aktywność korzystnych dla organizmu wybranych szczepów bakterii obecnych w jelicie grubym, na przykład nietrawiona skrobia, fruktooligosacharydy znajdujące się w roślinach, między innymi cebula, czosnek, por, cykoria, banany, szparagi. Dobroczynny wpływ prebiotyków na zdrowie człowieka (na przykład stymulacja układu immunologicznego do aktywności przy infekcji bakteryjnej lub wirusowej) muszą być naukowo potwierdzone (Bigos 2013, s. 13-124). Dzięki swoim właściwościom i korzystnemu wpływowi na procesy fizjologiczne zachodzące w organizmie ludzkim używane są w przemyśle spożywczym jako dodatek do fermentowanych produktów mlecznych: do jogurtów, serów i mleka acidofilnego. Funkcjonalne produkty mleczne wykazują 
między innymi działanie przeciwmiażdżycowe, przeciwnowotworowe, regulują właściwą masę ciała, wzmacniają odporność.

Produkty funkcjonalne mogą zawierać w swym składzie zarówno probiotyki, jak i prebiotyki (Kunachowicz, Kłys 2002, s. 35). Nazywane są wówczas synbiotykami, których fizjologiczny efekt prozdrowotny może wynikać z synergicznego działania obu aktywnych biologicznie składników.

\section{Oświadczenia żywieniowe i zdrowotne}

Rozwój żywności funkcjonalnej musi opierać się na wiedzy naukowej o jej celowym oddziaływaniu na organizm, zapewniającym zachowanie zdrowia, dobrego samopoczucia i/lub zmniejszenie ryzyka wystąpienia chorób. W Unii Europejskiej na szeroką skalę prowadzone są badania nad żywnością funkcjonalną, które dotyczą określenia nowych składników tej żywności i zdobywania akceptacji konsumentów dla takich produktów. W szczególności rozwijane są badania mające zidentyfikować potencjalne składniki funkcjonalne, korzystne dla zachowania zdrowia i dobrego samopoczucia, ustalające indywidualną, biologiczną reakcję na żywność funkcjonalną czy rozwijające właściwe biomarkery ${ }^{4}$ do szerokiego zastosowania $\mathrm{w}$ odniesieniu do procesu oddziaływania tych produktów (Walter 2008, s. 255). Badania mają na celu określenie użyteczności bioinformacji lub nanotechnologii w rozwoju żywności funkcjonalnej i zapewnienie stabilności w wytwarzaniu składników tej żywności (Functional Foods 2010, s. 17).

Programy ramowe w Unii dotyczą badań nad wpływem żywności funkcjonalnej na choroby układu krążenia (LYCOCAED, NUTRIDENT, FLAVIOLA), na system immunologiczny (TORNADO), na metabolizm (LIPGENE), choroby gastryczne (COLORSPORE) oraz oddziaływaniem probiotyków i prebiotyków na organizm człowieka (PROTECH, PROPATH, PROSAFE).

W ramach projektu naukowego FUFOSE, prowadzonego przez Międzynarodowy Instytut Badań nad Życiem (ILSI — Life Science Institute), zostały wyodrębnione i określone rodzaje oświadczeń dotyczących żywności funkcjonalnej. Kolejny projekt pod nazwą PASSCLAIM (Process for Assessment of Scientific Support for Claims on Foods - Proces Oceny Podstaw Naukowych Oświadczeń dotyczących Żywności), również koordynowany przez ILSI, zajmował się opracowaniem narzędzi badawczych dla oceny naukowej oświadczeń zdrowotnych. Wyniki przeprowadzonych badań zostały wykorzystane w przepisach prawnych odnoszących się do oświadczeń zdrowotnych i żywieniowych (Dz.Urz. L 404, s. 9). Stosowanie wymienionych oświadczeń ma zarówno chronić konsumenta, jak i zapewniać producentom podobne warunki konkurencji na jednolitym rynku i ułatwiać swobodny przepływ żywności.

${ }^{4}$ Biomarker (wyznacznik choroby) jest wymierną wielkością, jest powiązany z chorobą (i jej oceną). Wyznaczniki są często biochemicznymi składnikami, na przykład cholesterolu lub produktów rozkładu DNA. 
Oświadczenie żywieniowe informuje, że dany produkt spożywczy ma szczególne właściwości odżywcze ze względu na skład produktu, a oświadczenie zdrowotne wskazuje na wpływ produktu na zdrowie. Takie oświadczenia mogą być stosowane przy etykietowaniu, prezentacji i w reklamie żywności na jednolity rynek, gdy spełniają warunki podane w rozporządzeniu nr 1924/2006. W Unii Europejskiej dozwolone są, zgodnie z art. 2 przywołanego rozporządzenia, trzy typy oświadczeń:

1. oświadczenia żywieniowe, które stwierdzają, sugerują lub dają do zrozumienia, że produkt spożywczy ma szczególne własności dotyczące jego składu (odnośnie do wartości energetycznej lub zawartości określonych składników), przykładami oświadczeń tego typu są: „,źródło...”, „,bez zawartości...”, ,wysoka zawartość..." w odniesieniu do ilości kalorii lub poszczególnych składników;

2. oświadczenia zdrowotne, które stwierdzają, sugerują lub dają do zrozumienia, że istnieje związek między produktem spożywczym lub jednym z jego składników a stanem zdrowia, na przykład „wapń uczestniczy w budowie mocnych kości";

3. oświadczenia zdrowotne dotyczące zmniejszenia ryzyka choroby, które stwierdzają, że produkt spożywczy lub jeden z jego składników znacząco zmniejsza czynnik ryzyka choroby u ludzi.

Wymagane jest, żeby oświadczenia żywieniowe i zdrowotne były prawdziwe, jednoznaczne, niewprowadzające w błąd, nie budziły wątpliwości co do bezpieczeństwa lub adekwatności odżywczej żywności. Nie mogą zachęcać do nadmiernego spożycia danej żywności ani stwierdzać, sugerować lub dawać do zrozumienia, że zrównoważony sposób odżywiania się nie może zapewnić odpowiednich ilości składników odżywczych w ujęciu ogólnym ani odnosić do zmian w funkcjonowaniu organizmu w sposób wzbudzający lub wykorzystujący lęk u konsumenta przy pomocy tekstu, obrazu czy przedstawień graficznych lub symbolicznych (Dz.Urz. L 404, art. 3). Oświadczenia muszą być zrozumiałe dla przeciętnego konsumenta.

Oświadczenia zdrowotne i żywieniowe mogą być wykorzystywane po dokonaniu oceny przez Komisję i Europejski Urząd ds. Bezpieczeństwa Żywności (EFSA) oraz zamieszczeniu w odpowiednich wykazach. Wymienione oświadczenia dotyczą takiej żywności, która odpowiada ustalonym profilom składników odżywczych. Profile, w oparciu o wiedzę naukową na temat żywności i żywienia oraz ich wpływu na zdrowie, określa Komisja po uzyskaniu opinii naukowej EFSA. Zobowiązana jest także do przeprowadzenia konsultacji z przedsiębiorstwami działającymi na rynku spożywczym i grupami konsumentów. Przepisy rozporządzenia przewidują aktualizację profili odżywczych w miarę postępu naukowego ${ }^{5}$. Oświadczenia zdrowotne nie mogą być zamieszczane na napojach

5 Prace nad przepisami dotyczącymi profili składników odżywczych trwają z uwagi na konieczność uwzględnienia interesów gospodarczych sektora spożywczego, tradycji żywieniowych krajów członkowskich, a także presję polityczną. 
o zawartości alkoholu większej niż 1,2\% objętości (Szymecka-Wesołowska, Balicki, Szostek 2015, s. 51-54).

Stosowanie oświadczeń jest dozwolone, gdy właściwości lub działanie żywności jest potwierdzone ogólnie uznanymi dowodami naukowymi. Takie dowody mają potwierdzać, że brak lub obecność albo obniżona zawartość w danej żywności lub kategorii żywności składnika odżywczego lub innej substancji ma korzystne działanie odżywcze bądź fizjologiczne. Dowody naukowe, jak wskazała Komisja, muszą przede wszystkim obejmować badania z udziałem ludzi i zostać przedstawione zgodnie $\mathrm{z}$ hierarchią projektów badań oraz uwzględniać wytyczne Komisji i wskazówki przygotowane przez EFSA (Dz.Urz. L 109, s. 11).

Podmioty gospodarcze działające na rynku spożywczym mogą stosować tylko te oświadczenia zdrowotne, które zostały zatwierdzone w odpowiedniej procedurze i wpisane do wykazu dozwolonych oświadczeń. Wyróżniono trzy sposoby zatwierdzania oświadczeń. Jedną grupę stanowią oświadczenia generyczne zawarte w krajowych wykazach zdrowotnych przekazanych Komisji w celu ich włączenia do wykazu dozwolonych oświadczeń UE. Komisja miała przyjąć taki wykaz do 31 stycznia 2010 roku po zasięgnięciu opinii EFSA. $\mathrm{Z}$ uwagi na dużą liczbę przedstawionych wniosków termin opublikowania listy został przesunięty i podzielony na etapy. Pierwsza część wykazu została przyjęta na podstawie rozporządzenia Komisji nr 432/2012 i dotyczyła oświadczeń zdrowotnych z wyłączeniem oświadczeń o zmniejszeniu ryzyka choroby oraz rozwoju i zdrowia dzieci (Komunikat Komisji 2010). Istnieje jeszcze tak zwana lista oświadczeń oczekujących, na której znajdują się między innymi oświadczenia odnoszące się do substancji roślinnych lub ziołowych, wymagających dalszej oceny naukowej.

Drugi sposób wpisywania do wykazu dotyczy oświadczeń generycznych, opartych na nowo uzyskanych dowodach naukowych; to tak zwane oświadczenia innowacyjne oraz oświadczenia, w przypadku których wnioskodawca występuje o ochronę zastrzeżonych danych. Stosowana jest wówczas następująca procedura: zainteresowany składa wniosek o wydanie decyzji przez Komisję, a ta podejmuje stosowną decyzję po uzyskaniu od EFSA opinii naukowej. Tak wydano zezwolenie na rozpuszczalny w wodzie koncentrat pomidorowy, który pomaga utrzymać normalną agregację płytek krwi, co przyczynia się do zdrowego przepływu krwi (Szymecka-Wesołowska 2013).

Ostatni sposób dotyczy zatwierdzania oświadczeń o zmniejszaniu ryzyka choroby oraz oświadczeń o rozwoju i zdrowiu dzieci. W tym wypadku też wymagana jest opinia EFSA poprzedzająca wydanie stosownej decyzji przez Komisję (Dz.Urz. L 404, art. 15-17). Istnieje jeszcze procedura komitologii, w której uczestniczą EFSA, Komisja Europejska, Stały Komitet, Rada i Parlament Europejski, gdy EFSA wyda negatywną opinię. Podmioty uczestniczące w tej procedurze mogą zgłosić sprzeciw. 
Każdy podmiot działający na rynku spożywczym może stosować oświadczenie zdrowotne zawarte w wykazie dozwolonych oświadczeń, ale musi zachować wskazane tam warunki. Wyjątek stanowią oświadczenia, w stosunku do których zastrzeżono dane naukowe i inne informacje zawarte we wniosku (Dz.Urz. L 404, art. 21). Wykaz oświadczeń zdrowotnych łącznie z wykazem oświadczeń żywieniowych i odrzuconych oświadczeń zdrowotnych zamieszczony jest w rejestrze prowadzonym przez Komisję. Określone są tam też warunki stosowania dozwolonych oświadczeń. Rejestr jest publicznie dostępny na stronie Komisji: http:// ec.europa.eu./nuhclaims.

Na oświadczenia zdrowotne można się powołać przy prezentacji, reklamie i etykietowaniu produktu żywnościowego. W każdym przypadku wymagane jest dołączenie dwóch informacji obowiązkowych: o ilości środka spożywczego i poziomie jego spożycia niezbędnego do osiąnnięcia korzystnego działania oraz stwierdzenia wskazującego na znaczenie zrównoważonego sposobu żywienia i zdrowego trybu życia (Dz.Urz. L 404, art. 10, ust. 2). Dodatkowo w zależności od sytuacji należy ostrzec przed stosowaniem danego produktu przez określoną grupę osób lub o zagrożeniu zdrowia przy nadmiernym spożywaniu określonych produktów spożywczych. Na etykietach, przy prezentacji i reklamie można używać takich określeń, jak: ,pomaga utrzymać młodość”, „ma pozytywny wpływ na dobre samopoczucie". Innym przykładem jest stwierdzenie, że sterole roślinne sprzyjają zmniejszeniu stężenia cholesterolu w surowicy krwi, zmniejszając nasilenie jednego z czynników ryzyka chorób układu krążenia. Na etykietach produktów spożywczych dozwolone jest także odniesienie się do nazwy choroby, ale tylko po uzyskaniu zgody EFSA. Zakazane są natomiast oświadczenia zdrowotne:

1. sugerujące, że niespożycie danej żywności mogłoby mieć wpływ na zdrowie,

2. odwołujące się do szybkości lub wielkości obniżenia masy ciała,

3. odwołujące się do zaleceń poszczególnych lekarzy lub specjalistów w zakresie zdrowia, lub stowarzyszeń (Dz.Urz. L 404, art. 12).

W odniesieniu do drugiego zakazu mogą wystąpić trudności w odróżnieniu tego rodzaju oświadczeń od oświadczeń generycznych opisujących lub powołujących się na odchudzanie lub kontrolę wagi ciała albo zmniejszenie ilości energii dostępnej przy danym sposobie odżywiania. Te ostatnie oświadczenia mogą być stosowane po spełnieniu warunków rozporządzenia. Ostateczna ocena prawidłowości oświadczenia należy do EFSA i Komisji.

Przykładem oświadczeń zdrowotnych dotyczących witamin i minerałów ustalonych i potwierdzonych badaniami EFSA jest „działanie jako oksydanty stwierdzone w odniesieniu do witamin E i C oraz miedzi, manganu i selenu"; „oddziaływanie na system immunologiczny przez witaminy A, D, B6, B12, C oraz miedź, żelazo, cynk, selen”; „działanie na mięśnie przez witaminę D, wapń, miedź, potas i magnez" (Pravst 2012, s. 176). 


\section{4. Żywność funkcjonalna na rynku europejskim}

Sektor żywności funkcjonalnej w końcu XX i na początku XXI wieku charakteryzował wzrost wartości sprzedaży z 50\% do 60\%. Wskaźnik wzrostu żywności funkcjonalnej jest wyższy od średnio dwuprocentowego rocznego wzrostu liczonego dla sektora żywności jako całości (Manjula, Suneetha 2011, s. 879). Niewątpliwie rynek żywności funkcjonalnej jest najszybciej rozwijającym się sektorem światowego rynku żywnościowego. Szacuje się, że tempo wzrostu wynosi tu około $20 \%$ rocznie. Występują jednak różnice w szacunkach rozwoju tego rynku, wynikające z przyjętych definicji żywności funkcjonalnej i zakwalifikowania do niej odmiennych produktów. I tak roczny wzrost tego rynku jest też oceniany w granicach 7-10\%, a szacunki wielkości rynku różnią się znacznie — od 11 mld do 155 mld \$ rocznie. Z pojęciem żywności funkcjonalnej w wielu wypadkach łączone są bowiem nutraceutyki i naturalne produkty zdrowotne, co w opinii wielu autorów (Doyton, Labrecque 2005, s. 2) powoduje zamieszanie pomiędzy klasami produktów. Wartość światowego rynku żywności funkcjonalnej była szacowana w 2007 roku na 75 mld \$, a w 2012 roku na 95 mld \$ (Kudełka 2015, s. 18).

Eksperci badający światowy rynek żywności funkcjonalnej mają trudności z precyzyjnym ustaleniem danych dotyczących całkowitych obrotów i rozmiarów sprzedaży. Dostarczane są szacunkowe oceny takiego rynku; w 2002 roku wskazywano na wzrost do 47,6 mld \$, w 2004 do 34 mld \$, w 2005 do 81 mld \$, a w 2010 roku Euromonitor ocenił wartość światowego rynku żywności funkcjonalnej na 168 mld \$. Największy wzrost w przemyśle spożywczym dotyczył żywności zapobiegającej chronicznym chorobom i wynosił rocznie $8,6 \%$ za okres 10 lat, liczony do 2012 roku (Vicentini, Liberatore, Mastrocola 2016, s. 344).

Sprzedaż żywności funkcjonalnej jest skoncentrowana w trzech regionach: Japonii, Stanach Zjednoczonych i Europie, w których rosnący popyt na takie produkty zapewnia rozwój rynków krajowych. W 2013 roku szacowano średnie wydatki per capita na około 36 \$, a światowe obroty na około 252 mld \$. Największy procentowy udział w światowym dochodzie ogółem w sektorze żywności funkcjonalnej przypadł krajom Azji i Pacyfiku - 34\%, następne miejsce zajęła Ameryka Północna (USA i Kanada) - 25\%, Ameryka Łacińska - 17\%, Europa Zachodnia - 16\%, Europa Wschodnia oraz Kraje Bliskiego Wschodu i Afryka po 3\%, a na końcu znalazły się Australia i Nowa Zelandia - 2\%.

Zapotrzebowanie na żywność funkcjonalną w Europie jest różne w poszczególnych krajach, co wynika z kultury i tradycji kulinarnych. W państwach Europy Zachodniej oferowany jest szeroki asortyment produktów funkcjonalnych, odpowiadający konkretnym potrzebom grup konsumentów i tam osiągane są wyższe 
dochody z ich sprzedaży. Największy udział w łącznych dochodach ma Wielka Brytania (20\%), RFN (14\%), Francja (13\%), Hiszpania (12\%) i Włochy (11\%). W krajach Europy Wschodniej rynek żywności funkcjonalnej dopiero zaczął się rozwijać — wyróżniają się tu Polska (z udziałem 17\% w dochodzie ogółem) i Czechy (z udziałem około 9\%) (Vicentini, Liberatore, Mastrocola 2016, s. 345-346).

Tabela 1. Roczna procentowa stopa wzrostu w sektorze żywności funkcjonalnej na świecie w latach 2007-2013

\begin{tabular}{l|r|r|r|r|r|r}
\cline { 2 - 6 } & $\begin{array}{c}\mathbf{2 0 0 7 -} \\
\mathbf{2 0 0 8}\end{array}$ & $\begin{array}{c}\mathbf{2 0 0 8}- \\
\mathbf{2 0 0 9}\end{array}$ & $\begin{array}{c}\mathbf{2 0 0 9 -} \\
\mathbf{2 0 1 0}\end{array}$ & $\begin{array}{c}\mathbf{2 0 1 0}- \\
\mathbf{2 0 1 1}\end{array}$ & $\begin{array}{c}\mathbf{2 0 1 1}- \\
\mathbf{2 0 1 2}\end{array}$ & $\begin{array}{c}\mathbf{2 0 1 2}- \\
\mathbf{2 0 1 3}\end{array}$ \\
\hline Azja i wyspy Pacyfiku & 6,2 & 6,3 & 8,9 & 8,1 & 10,0 & 11,2 \\
\hline USA i Kanada & 4,8 & $-4,2$ & 1,4 & 5,5 & 1,4 & 4,6 \\
\hline Ameryka Łacińska & 11,1 & 8,5 & 12,8 & 12,9 & 12,4 & 13,1 \\
\hline Bliski Wschód i Afryka & 14,9 & 6,6 & 9,1 & 9,8 & 9,3 & 9,7 \\
\hline Australia i Nowa Zelandia & 6,7 & 6,6 & 7,9 & 8,1 & 5,2 & 6,1 \\
\hline Europa Zachodnia & 5,4 & 2,4 & 1,5 & 2,3 & 2,5 & 2,8 \\
\hline Europa Wschodnia & 20,6 & 1,6 & 7,7 & 11,0 & 9,2 & 10,2 \\
\hline
\end{tabular}

Źródło: Euromonitor 2013, cyt. za: Vicentini, Liberatore, Mastrocola 2016, s. 347.

W latach 2007-2013 tendencje zmian rocznej stopy wzrostu w sektorze żywności funkcjonalnej kształtowały się podobnie we wszystkich regionach poza Azją i wyspami Pacyfiku, gdzie stopa wzrostu stale rosła. W pozostałych regionach w latach 2008-2009 nastąpił spadek stopy wzrostu tego sektora, a w USA i Kanadzie nawet był ujemny $(-4,2 \%)$, w następnych latach ponownie zwiększała się stopa wzrostu sektora. Wyjątek stanowiły dwa regiony — USA i Kanada, gdzie w latach 2009-2010 i 2011-2012 zmniejszyła się stopa wzrostu, oraz Australia i Nowa Zelandia, gdzie obniżenie stopy wzrostu nastąpiło w latach 2011-2012. W krajach Europy Wschodniej roczne stopy wzrostu w sektorze żywności funkcjonalnej były większe niż w Europie Zachodniej, w której po spadkach w latach 2008-2010 powoli zwiększa się ten wskaźnik (zob. tabela 1).

Na rynkach żywności funkcjonalnej w Europie, według szacunków, dominują produkty mleczne (60\% udziału w rynku) i wyroby zbożowe (30\%) (Kudełka 2015, s. 21), występują też napoje funkcjonalne, wyroby cukiernicze, żywność dla niemowląt i tłuszcze. Różnice w szacunkach rynkowych wynikają z przyjętych definicji żywności funkcjonalnej i zaliczania do niej również produktów wzmocnionych witaminami i minerałami. $Z$ uwagi na liczbę oferowanych produktów przeważały napoje mleczne (209) i napoje (116), przy znacząco mniejszej liczbie pozostałych produktów żywnościowych (60) (zob. tabela 2). 
Tabela 2. Produkty żywności funkcjonalnej na rynku europejskim w 2004 roku

\begin{tabular}{l|c|c}
\hline \multicolumn{1}{c|}{ Sektor spożywczy } & Liczba produktów & Udzial procentowy \\
\hline Napoje mleczne (w tym jogurty) & 209 & 54,3 \\
\hline Napoje & 116 & 30,1 \\
\hline Produkty zbożowe & 19 & 5,0 \\
\hline Wyroby cukiernicze & 12 & 3,1 \\
\hline Tłuszcze i dodatki tłuszczowe & 12 & 3,1 \\
\hline Żywność dla niemowląt & 9 & 2,3 \\
\hline Inne produkty & 8 & 2,1 \\
\hline Razem & 385 & 100,0 \\
\hline
\end{tabular}

Źródło: IRC Scientific and Technical Reports 2008, s. 17.

$\mathrm{Z}$ uwagi na wpływ produktów funkcjonalnych na funkcjonowanie narządów i układów przeważa żywność oddziałująca na układ pokarmowy (45\%), krążenia (36\%) oraz odpornościowy (29\%) (Rynek żywności funkcjonalnej 2009, s. 22). Zwiększa się udział produktów funkcjonalnych przeciwdziałających starzeniu się, pozytywnie działających na układ kostny i pozwalających utrzymać odpowiednią wagę ciała (Tomaszewska et al. 2014, s. 295). Na rynku europejskim występuje również żywność funkcjonalna służąca:

— poprawie funkcjonowania układu pokarmowego — w postaci jogurtów i napoi probiotycznych, płatków śniadaniowych z probiotykami;

— zmniejszeniu ryzyka chorób układu krążenia — oleje roślinne, margaryna Benecol, Flora pro-active, czekolada mleczna z antyoksydantami, napoje probiotyczne;

— zmniejszeniu otyłości i nadwadze — produkty o obniżonej zawartości tłuszczu i cukru, ekstrakty z ziół, preparat Fabuless na obniżenie apetytu, herbaty funkcjonalne;

— zapobiegające osteoporozie — biszkopty wzbogacone w wapń, kwas foliowy, żelazo i inulinę;

— poprawiające wygląd skóry — jogurt Essensis zawierający ProNutris (preparat witaminowy);

— przeciwdziałaniu starzeniu się - mleko z dodatkiem selenu, cynku, witamin E, A i D, magnezu i błonnika, napój z kolagenem i witaminami Collalift, marmolada Noreva;

— przeciwdziałaniu stresowi - ekstrakty z zielonej herbaty i ziół, tak zwane nocne mleko (mleko krowie z serotoniną), czekoladki GABA, napoje;

- alergikom (produkty niezawierające glutenu, soi, laktozy) — w postaci napoi, wyrobów mącznych, mlecznych, cukierniczych; 
— poprawie wydolność psychofizycznej — napoje energetyzujące, cukry naturalne, napoje izotoniczne (Kudełka 2015; Rynek żywności funkcjonalnej 2009, s. 23).

Cechą wyróżniającą rynek żywności funkcjonalnej jest ciągłe zwiększanie się liczby takich produktów, gdyż nieustannie udowadnia się funkcjonalność coraz większej liczby składników żywności. Przykładem mogą być napoje mleczne, serki funkcjonalne firmy Danone, Zott, a także produkty wysokoproteinowe: jogurty, napoje.

\section{Wnioski}

Z różnorodnych definicji żywności funkcjonalnej wynika, że jest to produkt spożywczy, a nie tabletka czy kapsułka, otrzymany z naturalnie występujących składników lub modyfikowanych. Poza funkcją odżywczą ma działanie prozdrowotne: zwiększa odporność organizmu, przeciwdziała chorobom, sprzyja leczeniu określonych chorób, dobremu stanowi fizycznemu i psychicznemu czy hamuje procesy starzenia. Potwierdzenie oddziaływania na poprawę stanu zdrowia ludzi wymaga przeprowadzenia badań i ich udokumentowania. Badania stanowią podstawę do uzyskania prawa do stosowania oświadczeń żywieniowych i oświadczeń zdrowotnych. Przepisy rozporządzenia nr 1924/2006 nakładają na podmioty gospodarcze obowiązek udokumentowania badań. Ważna jest współpraca między ośrodkami naukowymi i przemysłem spożywczym, tak aby uzyskiwane wyniki badań umożliwiały komercyjne wykorzystanie większej ilości funkcjonalnych komponentów żywności.

Dla bezpieczeństwa konsumenta spożywającego żywność funkcjonalną istotna jest rzetelność i uczciwość prowadzonych badań naukowych nad wpływem żywności i jej składników na zdrowie człowieka. Należy także zwrócić uwagę, że czynnikiem ograniczającym rozwój rynku żywności funkcjonalnej są przepisy prawne i procedury dotyczące oświadczeń zdrowotnych i żywieniowych, które wymagają ponoszenia przez przedsiębiorców kosztów na uzasadnienie zdrowotnego wpływu na organizm człowieka żywności lub jej składników.

\section{Bibliografia}

Ashwell M. (2001), Functional foods: a simple scheme for establishing the scientific validity for all claims, www.M.Ashwell-funk.food.pdf (dostęp: 27.04.2013).

Asp N.G. (2002), Health claims within the Swedish Code. Generic claims and product - specific physiological claims in relation to current European and international developments, „Scandinavian Journal of Nutrition" 46, s. 131-136, www.foodandnutritionresearch.net/index.php/ fnr/ article/.../1318 (dostęp: 25.04.2013).

Ekonomia - Wroclaw Economic Review 23/4 (2017)

(C) for this edition by CNS 
Bigos M. (2013), Patologia infekcyjna - znaczenie odporności populacyjnej, probiotyki i prebiotyki, [w:] Zagrożenia zdrowia publicznego. Zdrowie człowieka a środowisko, red. A. Denys, cz. 2, Warszawa, s. 119-130.

Doyon Z., Labrecque J.A. (2005), Functional foods: a conceptual definition, www.Funk.foodconcept.def.pdf (dostęp: 24.01.2014).

European Commission Directorate - General for Research (2010), Functional Foods, http://ftp. cordis.europa.eu/pub/fp7/kbbe/docs/functional-foods_en.pdf (dostęp: 24.01.2013).

Grajeta H. (2004), Żywność funkcjonalna w profilaktyce chorób układu krążenia, http://www.dbc. wroc.pl/Content/2303/x-17_Graj.pdf (dostęp: 24.01.2013).

Holm F. (2000), Nowa żywność funkcjonalna czynnikiem wplywającym na zdrowy układ sercowo-naczyniowy, www.pttz.org/raporty/zywnosc-fun.doc (dostęp: 24.01.2013).

Komunikat Komisji (2010), Food: Commisssion reviews the progressive adoption of the list of permitted health claims, European Commission Press Releases IP/10/1176.

Kubiński T. (2010), Żywność funkcjonalna, „Życie Weterynaryjne” 85, s. 932-935.

Kudełka W. (2011), Innowacyjny segment żywności wspierającej zdrowie człowieka, http://www. uni.rzeszow.pl/pliki/Zeszyt18/22pdf (dostęp: 20.03.2013).

Kudełka W. (2015), Żywność a zdrowie i uroda, www.zywnosc\%20zdrowie\%20uroda.pdf (dostęp: 30.04.2017).

Kunachowicz H., Kłys W. (2002), Żywność funkcjonalna. Wpływ dodatku prebiotyków i probiotyków na wartość odżywcza żywności. Pediatria wspótczesna, „Gastroenterologia, Hepatologia i Żywienie Dziecka" 4, s. 34-46.

Malla S. et al. (2013), Assessing the Functional Foods and Natural Health Products Industry: A Comparative Overwiew and Literature Review.

Manjula K., Suneetha C. (2011), Designer foods - their role in preventing life style disorders, „International Journal of Science and Nature” 2 (4), s. 878-882.

Pravst I. (2012), Functional foods in Europe: A focus on health claims, http://www.intechopen.com/ books/scientific-health-and-social-aspects-of-the-food-industry/functional-foods-ineurope-a-focus-on-health-claims (dostęp: 27.01.2013).

Raport. Rynek żywności funkcjonalnej. Wzrost za jaka cenę? (2009), s. 22-28, www.Zywn.funkc. Raport.pdf (dostęp: 24.01.2013).

Roberfroid M.B. (2002), Global view on functional foods: European perspectives, „British Journal of Nutrition" 88, s. 133-158.

Rozporządzenie Parlamentu Europejskiego i Rady nr 1924/2006 z dnia 20 grudnia 2006 r. w sprawie oświadczeń żywieniowych i zdrowotnych dotyczących żywności, Dz.Urz. L 404 z 30 grudnia 2006 r., s. 9-25.

Rozporządzenie Komisji nr 353/2008 z dnia 18 kwietnia 2008 r. ustanawiające przepisy wykonawcze w odniesieniu do wniosków o wydanie zezwolenia na stosowanie oświadczeń zdrowotnych zgodnie z art. 15 rozporządzenia nr 1924/2006 Parlamentu Europejskiego i Rady, Dz.Urz. L 109 z 19 kwietnia 2008 r., s. 11.

Rozporządzenie Komisji nr 432/2012 z dnia 16 maja 2012 r. ustanawiające wykaz dopuszczonych oświadczeń zdrowotnych dotyczących żywności, innych niż oświadczenia odnoszące się do zmniejszenia ryzyka choroby oraz rozwoju i zdrowia dziecka, Dz.Urz. L 136 z dnia 25 maja 2012 r., s. 1.

Saluk-Juszczak J. et al. (2010), Żywność funkcjonalna - rola nutraceutyków w profilaktyce chorób uktadu krażenia, „Kosmos. Problemy Nauk Biologicznych” 3-4, s. 527-538.

Stein A.J., Rodrigues-Cerezo E. (2008), Functional Food in the European Union, „IRC Scientific and Technical Reports, http://ftp.jrc.es/EURdoc/JRC43851.pdf (dostęp: 25.04.2017).

Szymecka-Wesołowska A. (red.) (2013), Bezpieczeństwo żywności i żywienia. Komentarz, https:// sip.lex.pl/\#/komentarz/587351345/148785 (dostęp: 24.03.2017).

Ekonomia — Wroclaw Economic Review 23/4 (2017)

(C) for this edition by CNS 
Szymecka-Wesołowska A., Balicki A., Szostek D. (red.) (2015), Oświadczenia żywieniowe i zdrowotne w oznakowaniu, prezentacji i reklamie żywności. Komentarz, https://sip.lex.pl/\#/kome ntarz/587351371/148811?tocHit=1\&cm (dostęp: 20.03.2017).

Tomaszewska M. et al., Żywność funkcjonalna jako możliwość rozwoju polskich firm spożywczych, „Stowarzyszenie Ekonomistów Rolnictwa i Agrobiznesu. Roczniki Naukowe” 16, z. 3, s. 293-298.

Vicentini A., Liberatore L., Mastrocola D. (2016), Functional foods: Trends and development of the global market, „Italian Journal of Food Science” 22, s. 338-351.

Walter P. (2008), 10 years of functional foods in Europe, „International Journal for Vitamin and Nutrition Research" 6, s. 253-260.

Włodarek D. (2006), Żywność funkcjonalna i wzbogacona, „Żywność dla Zdrowia” 4, s. 22-25. 